\title{
Decalogue for sustainable urban transport strategy
}

\author{
J. Malasek \& A. Jaździk-Osmólska \\ Road and Bridge Research Institute, Warsaw, Poland
}

\begin{abstract}
Sustainable urban planning is a chance for improvement, or at least not worsening, living standards in a metropolis, where streets over packed by cars make cities less attractive not only for inhabitants, but also for visitors and investors. Time is money, and traffic jams cause the big time losses as well as environmental problems with higher emission and noise. Achievement of sustainable city growth needs the full coordination of transport and spatial planning policies.

The main groups of activities for sustainable urban development stimulation are: city development along main transport corridors with high quality public transport (PT) modes, making land use more intensive and multifunctional and restrictions for car use in downtown areas.

Policy packages in the city scale should be supported by the national policy for sustainable development. 10 measures or commandments, let's call it the Decalogue for Sustainable Urban Transport Strategy, could be very helpful here. The 10 commandments are: promotion of public transport modes, car restrictions in the cities, fuel prices can never go down, ecological transport tax, promotion of more environmental friendly vehicles, equal access to PT modes, co-financing of transport investments, sustainable spatial planning policy, better telecommunication services and better goods transport management.

Keywords: transport strategy, sustainability, urban planning.
\end{abstract}

\section{Introduction}

The biggest challenge of sustainable transportation policy in urban areas is to decrease car use in densely populated areas where the highest traffic flows are observed. Although the idea of sustainability is well known since the 1980s, it 
will be useful for this paper to explain how it is understood here. Implementing sustainable development [1] is to support economical growth with minimal harm for environment and high living standards. In case of sustainable transport it means less energy and land consuming investments. As mobility is one of important living standards and big achievement of our civilization, we have to be sure that any restrictions for car use will not decrease an indispensable mobility. Keeping only indispensable mobility in mind means that policy measures should try to reduce need for car using by other solutions, like:

- Better communication,

- Attractive public transport,

- Modern land use, and last not lease

- Clever and sound transportation policy.

Good use of a better communication can substitute a lot of travels. Internet and other telecommunication services can substitute:

- $\quad$ personal meetings (you can call, fax or send e-mail)

- $\quad$ everyday work trips by tele-work (working at home)

- business trips (visiting bank, city administration, etc.)

- looking for goods in shops.

Attractive public transport means:

- $\quad$ quick travel by preferences in traffic (separated right-of-way for trams, bus lanes, priority at junctions, etc.)

- $\quad$ cheap (subsidized) tickets

- $\quad$ short, convenient and safe walking distance to mass transit stops

- $\quad$ short waiting time by small headways (smaller vehicles were needed) or reliable time tables and well organized interchanges

- call-and ride services mostly for handicapped.

Land-use planning in urban areas [2] should follow such rules as:

- work close home (because of big achievements in making industry clean, no longer need to separate workplaces according to the Athen's Charter)

- $\quad$ shops close home (hypermarkets generate high volumes of car traffic)

- main trip generators (high-rise office buildings, shopping malls, sport arenas, etc.) close public transport interchanges

- $\quad$ in general: multifunctional and intensive land use should be promoted

- $\quad$ fighting urban sprawl (low density generate additional car traffic) using financial and administrative measures.

Coordination of spatial \& transport planning policy [3] means:

- balance in the CBD of three capacities: internal road network = external access roads $=$ internal parking lots

- $\quad$ parking zones - standards for maximum parking spaces per 1000 sq.m. of offices in CBD and minimum in the outskirts with law density

- Park-and Ride system with parking reserves close to mass transit terminals outside downtown area

- bicycle routes network development

- well facilitated pedestrian areas. 
Measures mentioned above do not include enforcement like parking and road pricing, limited access to specified areas, etc. Enforcement can help policy implementation and usually is quite effective, but the more elegant solution is to attract people to other transport modes than to forbid car use administratively.

\section{0 commandments for sustainable urban transport}

In the cities, regions or even the countries facing really big transportation problems, soft measures mentioned above should be supported by the more painful administrative decisions [4]. 10 measures or commandments, let's call it the Decalogue for Sustainable Urban Transport Strategy, could be very helpful here.

\section{Promotion of public transport modes}

Better accessibility and higher attractiveness of public transport modes_can be done by:

- Development of high quality public transport networks, even when it decrease the road capacity

- Preferences for public transport vehicles in traffic

- More convenient interchanges

- Convenient and environmental friendly public transport vehicles

- Good national passenger information system

II. Car restrictions within the cities

Can be done by high charging of using more cars in a household and limiting their number to 1 in case of households in parking charging zones.

\section{Fuel prices can never go down}

Lowering fuel price makes people who choose public transport because of economical reasons going back to the car use. Profit gained when the market fuel price goes down should feed the city fund for public transport development.

\section{Ecological transport tax}

Each car ride is automatically taxed and the tax amount depends on the city district, journey length, emissions, the noise level and on the day time (the highest during pick-hours).

V. $\quad$ Promotion of more environmental friendly vehicles

Buying the more expensive hybrid or electric car should be awarded with a couple of gains, connected with its purchase (lower VAT and registration fees) and use (entering limited access zones, lower parking fees, etc.).

\section{Equal access to PT modes}

Can be done by arranging better conditions of functioning in the city environment for the handicapped and those who can not use private vehicles, and are fully depend on the city transport.

\section{Co-financing of transport investments}

All real estate owners should participate (by paying the higher tax) in financing all local investments which increase accessibility of their houses, flats and plots. 


\section{Sustainable spatial planning policy}

Revitalization of urban areas with multifunctional and intensive land use, which makes that transportation needs are lower and more journeys can be covered by walking and cycling.

\section{Better telecommunication services}

Access for everyone to high quality telecommunication and Internet networks, which can in many cases substitute travels and, what's probably the most important, makes tele-working possible.

\section{$X$. Better goods transport management}

Deliveries within the city should be served in smaller (instead of HGV) and more environmental friendly (using alternative fuels) vehicles or, if only possible, by train.

Obviously, final decision on implementation of all measures mentioned above should be done during public participation process attended by all main groups of the city stakeholders.

\section{Public opinion on sustainability measures}

The survey was conducted by the Road and Bridge Research Institute during the X-th Public Transport Days on 17-18 September 2011 in Warsaw, as part of the European research project GUTS - Green Urban Transport Systems [5]. The main task of this survey (spontaneous survey $[6,7]$ ) was to learn the Warsaw inhabitants attitude to 10 commandments described in Chapter 2. Additional survey questions were developed to allow comparisons with the results of the last Warsaw Travels Survey (WBR 2005) [8].

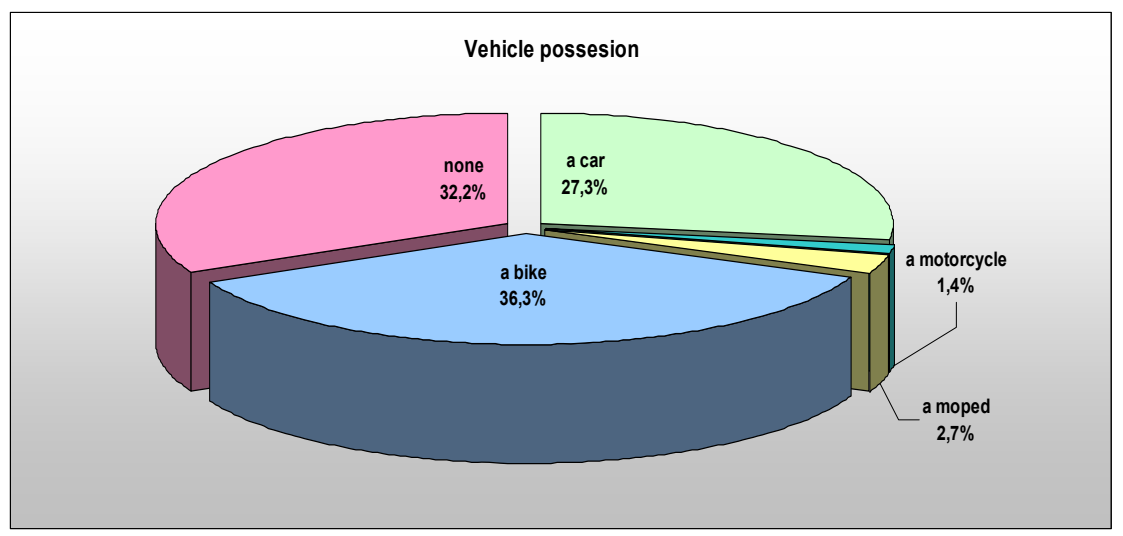

Figure 1: Declared possession of vehicles.

347 respondents fully filled-in the questionnaire, including 188 men $(54.2 \%$ of respondents) and 159 women (45.8\%). The largest age group were people 25 39 years old $(36.9 \%)$ and people over 60 made $8 \%$ of all respondents. Travel time to work/school for $30 \%$ of respondents is $15-30$ minutes. Less than 15 minutes takes a journey in case of $24 \%, 30-45$ minutes declare 22\%, 45-60 
minutes $16 \%, 60-90$ minutes $5 \%$ and for $3 \%$ of all respondents travel time is longer than 90 minutes. Further characteristics of respondents are shown on Figures 1 and 2.

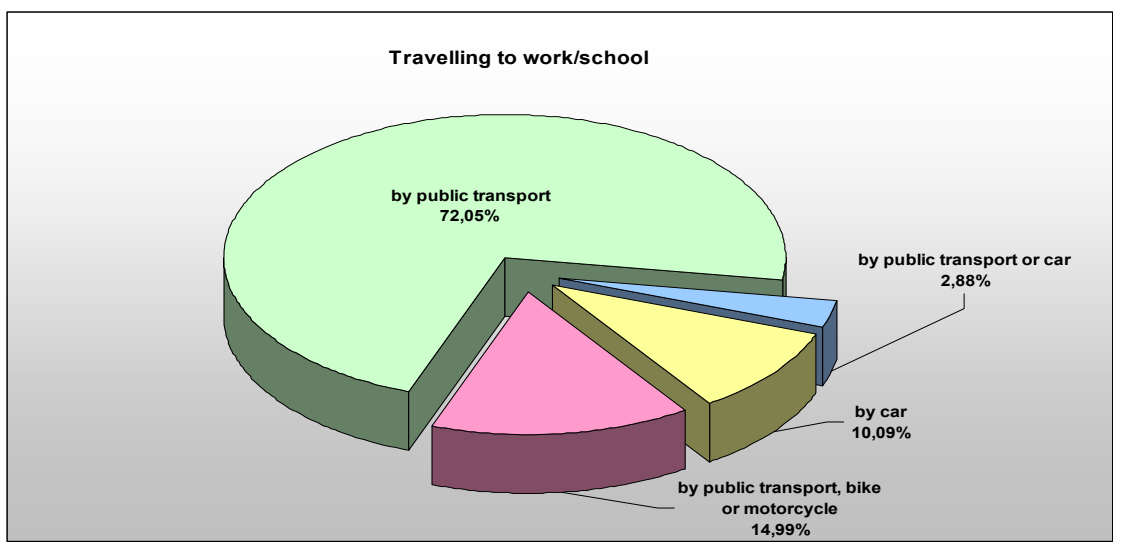

Figure 2: Choice of travel mode for commuting to work and school.

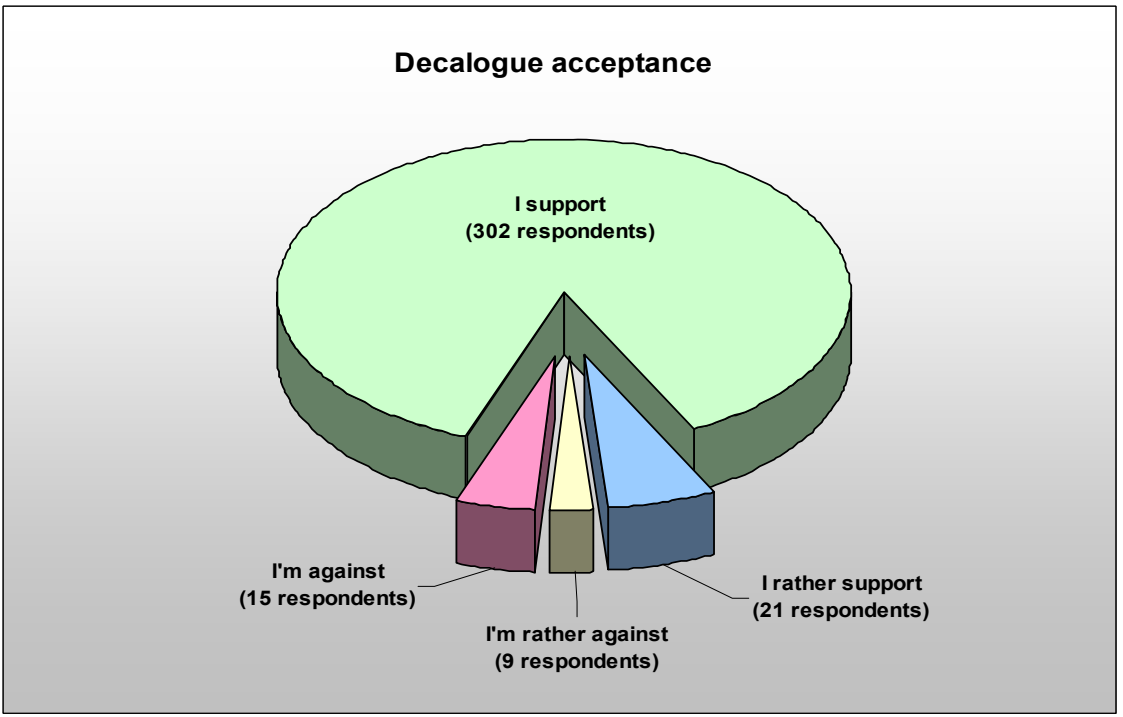

Figure 3: $\quad$ Support for enforcement of ecological behavior.

The vast majority of our respondents (see Fig. 3) supported very tough measures suggested in the Decalogue. Some examples of the most interesting or typical opinions (in four categories of acceptance) are quoted below. 


\section{* I'm against:}

It's eco-fascism; absurdity; a robbery of our money; people will not stop driving cars because public transport on the city outskirts is rather poor.

\section{* I'm rather against:}

Some proposals are acceptable, but: I don't agree for the higher fuel prices; I need 2 cars in my household and don't like to have any limits in it.

\section{* I rather support:}

I accept most of the suggested measures, but: people can't pay too much for making transport system more environmental friendly, money for it should be found in the city or governmental budgets.

\section{* I support:}

At last someone suggests a comprehensive strategy for living standard improvements in Warsaw. Everything what makes public transport more attractive for passengers is OK. The experience of other European metropolis shows that such an approach provides high measurable benefits.

It clearly looks people in Warsaw strongly vote for fighting traffic jams and making travelling less time consuming and more pleasant. Why they are so highly determined explain next figures, answering questions on public assessment of urban road infrastructure, public transport services and environmental issues. In 1-10 scale 10 means excellent.

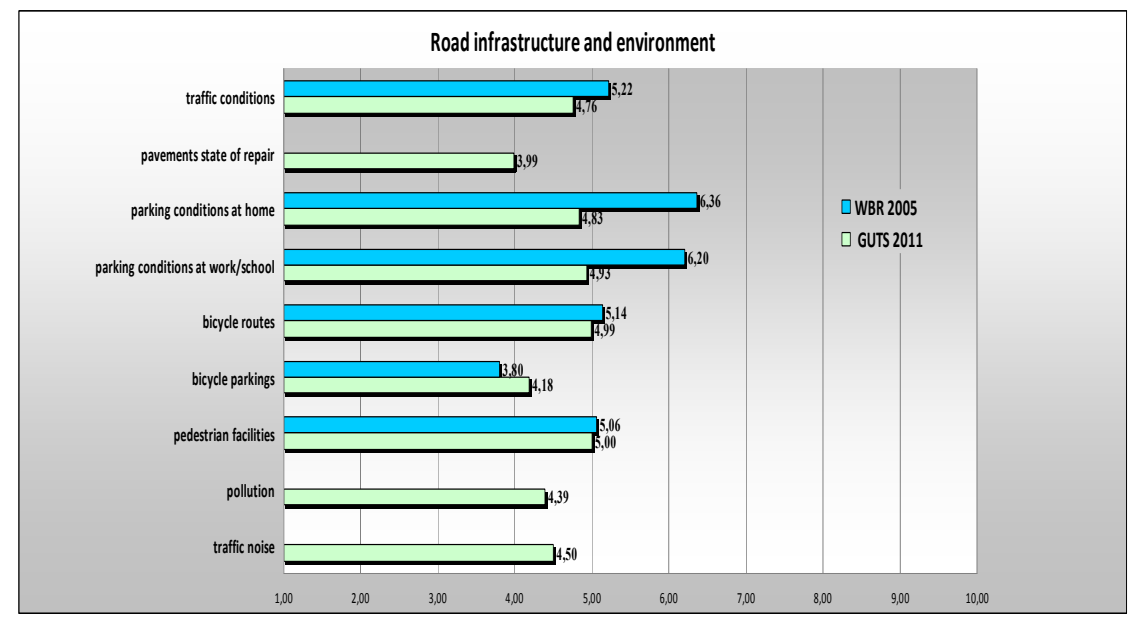

Figure 4: Evaluation of road and quality of city environment.

Figures 4 and 5 show also trends in public assessment of particular elements of the Warsaw transport system, comparing (where possible) their present attitude with that during travel survey (WBR) made in 2005. 


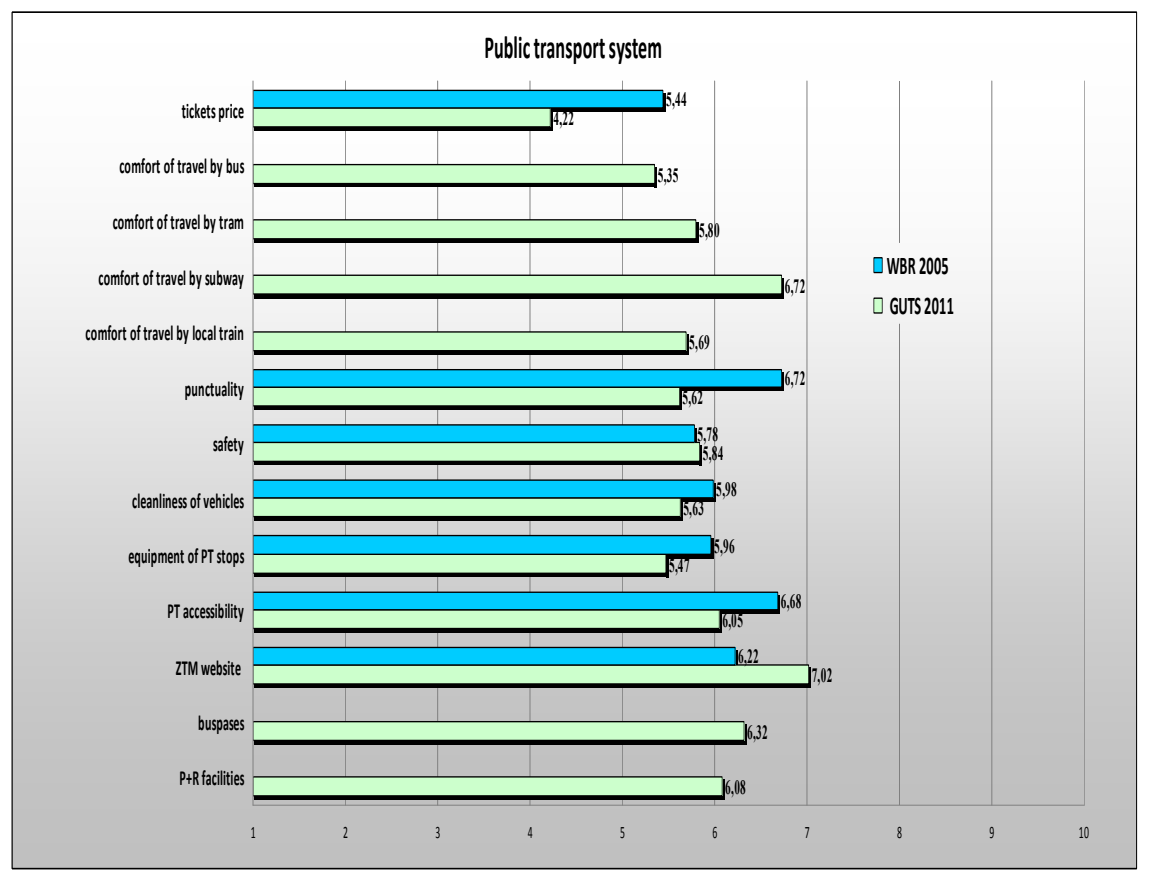

Figure 5: Evaluation of public transport services.

Do you agree for enlarging parking charging zone?

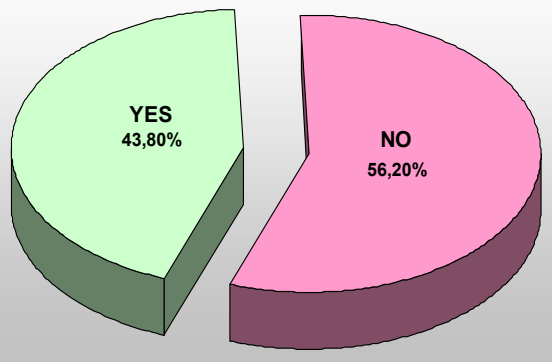

Figure 6: Evaluation of parking preferences. 


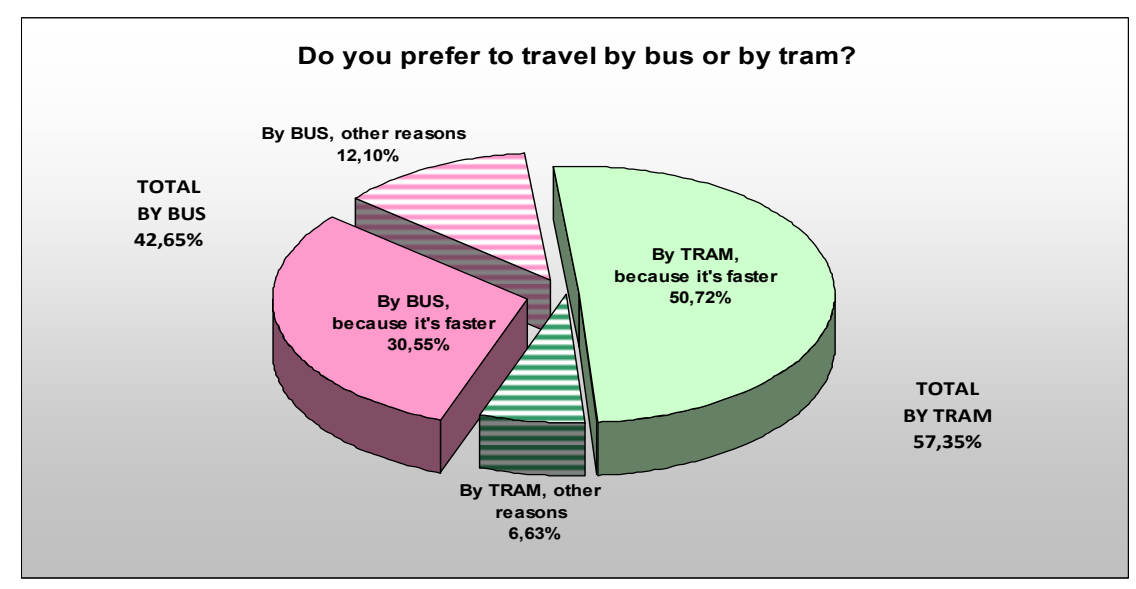

Figure 7: $\quad$ Travel mode preferences.

\section{Conclusions}

1. Sustainable transport means energy savings and less land consuming investments.

2. Transportation policy measures should at first attract people to other transport modes, not using enforcement connected with car restrictions.

3. Commandments of the Decalogue for Sustainable Urban Transport Strategy should be used only in emergency, after checking all available soft measures.

4. The vast majority of Warsaw inhabitants support very tough measures suggested in the Decalogue.

5. Since 2005 in Warsaw only ZTM (Warsaw Public Transport Authority) website, passenger safety and bicycle parking facilities have improved.

6. Our respondents found poorer than 6 years ago: traffic and parking conditions, bicycle routes and pedestrian facilities, tickets price, PT accessibility, PT stops equipment, punctuality and cleanliness of PT vehicles.

7. Very encouraging for further implementation of sustainable urban transport policy is public support for enlargement of the parking charging zone and for development of the tram network.

\section{References}

[1] Malasek, J., Pakiety wdrożeniowe koordynacji miejskiej polityki transportowej z polityka zagospodarowania przestrzennego (Implamentation packets for coordination of transportation and spatial planning polices), TMiR: 2011.

[2] Land Management and Mobilization in Europe; Regimes, Polices and Processes, COST Office: 2010. 
[3] Land Management for Urban Dynamics. Innovative Methods and Practices in a Changing Europe, DICATA - University of Brescia: 2011.

[4] Priebs, A., Transport and Spatial Polices: The Role of Regulatory and fiscal Incentives, Economic Research Centre: 2002.

[5] http://www.gutscentral.eu/.

[6] Nowak, S., Metodologia badań społecznych (Methodology of social research), Biblioteka Socjologiczna - PWN: 2011.

[7] Zeliaś, A., Metody statystyczne (Statistical methods), PWE: 2000.

[8] Warszawskie Badanie Ruchu 2005 (Warsaw Travels Survey 2005), Miasto Stołeczne Warszawa - BPRW S.A.: 2005.

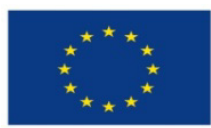

EUROPEAN UNION

EUROPEAN REGIONAL

DEVELOPMENT FUND

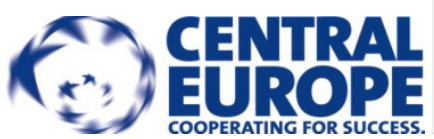

